\title{
Making the most out of the least: new insights into congenital diaphragmatic hernia
}

\author{
Hratch L Karamanoukian, Stuart J O’Toole, Bruce A Holm, Philip L Glick
}

Congenital diaphragmatic hernia $(\mathrm{CDH})$ has an incidence of between 1:2000 and 1:5000 live births. ${ }^{1}$ A posterolateral diaphragmatic defect allows abdominal viscera to herniate into the thoracic cavity early in gestation, inhibiting normal fetal lung growth and development. ${ }^{23}$ Other pathophysiological features such as pulmonary hypertension, surfactant deficiency, and left ventricular hypoplasia may act synergistically to produce a mortality exceeding $60 \%$ even in the era of extracorporeal membrane oxygenation. ${ }^{14}$ New insights into the pathophysiology of $\mathrm{CDH}$ will be reviewed and new treatment strategies emphasised.

\section{Pulmonary hypoplasia, pulmonary hypertension and surfactant deficiency}

A considerable reduction in the number of bronchial divisions occurs during development which is more severe on the ipsilateral side. ${ }^{5}$ Bronchial divisions are arrested at 10-12 weeks on the side of the hernia and at 12-14 weeks on the contralateral side. This causes an overall reduction in the gas exchange area. In addition, the lungs appear to be arrested in the saccular phase of development. It has been argued that many infants dying of CDH have "lethal pulmonary hypoplasia". ${ }^{6}$ However, this doesn't explain the "honeymoon period" during which they have adequate oxygenation and ventilation, but then deteriorate regardless of treatment. ${ }^{6}$ Recently adopted "alveolar recruitment strategies" may help to explain this dichotomy. ${ }^{7-9}$

The lungs of patients with $\mathrm{CDH}$ have been found to have a decrease in size of the vascular bed, ${ }^{10}$ abnormal muscularisation of the acinar arteries, ${ }^{10}$ and an increased sensitivity to stimuli of pulmonary vasoconstriction. ${ }^{11}$ The pulmonary vasculature cannot accept all of the right ventricular output at birth, resulting in the shunting of blood across the ductus arteriosus and foramen ovale. Although there has been an intensive search for mediators that cause pulmonary vasoconstriction in $\mathrm{CDH}$, no single culprit has been identified. Endothelin-1, a potent vasoactive peptide, is increased during episodes of pulmonary hypertension, but the complicated actions of this protein make it difficult to determine whether it causes pulmonary vasoconstriction or is produced in response to it. ${ }^{1213}$ Increased thromboxane levels have also been found with episodes of pulmonary hypertension, but again results are confusing and the clinical significance unknown. ${ }^{14-16}$ In addition, there is no evidence to suggest that there is a deficiency of nitric oxide (NO) production in $\mathrm{CDH}$. Pulmonary nitric oxide synthase production has been shown to be identical in both surgically created $\mathrm{CDH}$ and control fetal lambs at term. ${ }^{17}$ Nitric oxide synthase (NOS) activity was found to remain at control levels following ventilation, suggesting that a deficiency of NO production does not contribute to the pathophysiology of pulmonary hypertension in the surgically created lamb model of CDH. ${ }^{17}$ Interestingly, decreased pulmonary NOS activity has been shown to be a pathophysiological feature in the nitrofen induced rat model of $\mathrm{CDH} .{ }^{18}$ Therefore, although an imbalance between vasodilators and vasoconstrictors has been hypothesised to explain the pathophysiology of pulmonary hypertension in $\mathrm{CDH}$, others have maintained that pulmonary hypertension is an avoidable iatrogenic complication caused by aggressive ventilation and chest drainage. ${ }^{19}$ It is believed that increased transpulmonary pressure causes perivascular emphysema and pulmonary hypertension (the "air block syndrome") with surfactant deficiency being the reason.

Histological, morphological, and biochemical similarities have been noted between the lungs of babies with respiratory distress syndrome and those with $\mathrm{CDH} .{ }^{20}$ Infants diagnosed prenatally with $\mathrm{CDH}$ have immature lecithin sphingomyelin (L/S) ratios and reduced levels of phosphatidyl glycerol (PG) in the amniotic fluid. ${ }^{2122}$ The fetal lamb model of $\mathrm{CDH}$ has been shown to have a quantitative and qualitative reduction in lung surfactan $\mathrm{t}^{23}$ with reduced total lung capacity and decreased compliance. A significant increase in lung compliance, total lung capacity, and oxygenation have been found in fetal $\mathrm{CDH}$ lambs treated prophylactically with surfactant (Infasurf; ONY Inc, Buffalo, New York, USA) ${ }^{24} 25$ with a dramatic fall in pulmonary vascular resistance and subsequent increase in pulmonary blood flow. ${ }^{26}$ This indicates that a portion of the pulmonary hypertension in $\mathrm{CDH}$ is due to alveolar instability and inadequate recruitment of all alveoli in a non-compliant lung.

\section{Selection criteria for antenatal therapy}

Timely fetal surgical correction of the diaphragmatic hernia has been shown to reverse both the pulmonary hypoplasia and the pulmonary vascular abnormalities in $\mathrm{CDH}^{27} \mathrm{Se}-$ lection criteria for in utero surgical correction of $\mathrm{CDH}$ remains ill defined. ${ }^{2829}$ It is still impossible to determine prospectively which fetuses with $\mathrm{CDH}$ will survive the gestational or neonatal period, as only these groups should be candidates for repair of the diaphragmatic hernia in utero. The major challenge has been to identify prenatal risk factors in the fetus that will accurately select potential candidates for fetal surgery. Antenatal diagnosis before 25 weeks gestation has been used as the sole indication for fetal surgery, based on the finding that prenatally diagnosed $\mathrm{CDH}$ is associated with a mortality of $88 \% .{ }^{30}$ Others have shown that fetal age at diagnosis, polyhydramnios, dilated stomach in the chest, and mediastinal shift are limited in their prognostic usefulness and do not assess "fetal lung function" or neonatal outcome. ${ }^{252731}$ However, the "hidden mortality" in $\mathrm{CDH}$ is not entirely due to aberrant lung development. ${ }^{2932}$ Human necropsy studies and studies in the fetal lamb model have demonstrated left ventricular "smallness" in CDH. ${ }^{3334}$ Prenatal echocardiography has shown that ventricular disproportion (decreased left ventricular to right ventricular internal diameter ratios) noted before 24 weeks gestation is associated with a $100 \%$ mortality. ${ }^{3536}$ It has been speculated that such structural data generated echocardiographically as early as the pseudoglandular stage of lung development may be helpful in identifying fetuses with $\mathrm{CDH}$ that have lethal pulmonary hypoplasia. ${ }^{37}$ Consequently, it has been suggested that the heart may be the "missing link" in the treatment algorithm 
used to determine which fetuses should be considered for fetal surgery and which should be managed with state of the art postnatal care. ${ }^{2932}$

Tracheal ligation, also referred to as "PLUG" (Plug the Lung Until it Grows), has been shown to reverse the pulmonary hypoplasia by accelerating fetal alveolar growth, and to reverse the pulmonary vascular abnormalities in CDH..$^{3839}$ However, significantly decreased total phospholipid content by bronchoalveolar lavage and decreased surfactant synthesis by the type II pneumocytes in $\mathrm{CDH}$ have been described following tracheal ligation. ${ }^{40}$ The clinical significance of these findings remains unknown as most animal data have been limited to short periods of study. ${ }^{40}$ Long term studies are necessary to determine the clinical significance of these biochemical findings.

\section{Postnatal therapy}

If conventional mechanical ventilation does not stabilise the neonate with $\mathrm{CDH}$, then alternative methods of oxygenation and ventilation should be considered. The primary abnormality of neonates with $\mathrm{CDH}$ who develop or maintain severe respiratory distress results from persistence of the fetal circulation - increased pulmonary artery pressures, increased pulmonary vascular resistance, and rightto-left shunting at the foramen ovale and the ductus arteriosus. This results in a vicious cycle of hypercarbia, acidosis, and progressive hypoxaemia. Surfactant therapy has been advocated even when the L/S ratio is normal, as bronchoalveolar lavage data have shown a qualitative and quantitative deficiency in surfactant phospholipids. ${ }^{4142}$ Infasurf (ONY Inc, Buffalo, New York, USA) should be administered intratracheally in a dose of $100 \mathrm{mg} / \mathrm{kg}$ before the first delivered breath. ${ }^{23-254344}$ Infasurf is a calf lung surfactant extract which includes surfactant associated proteins B and C. It has theoretical efficacy over the most commonly used artificial surfactant preparations Exosurf (Burroughs Wellcome, Research Triangle Park, North Carolina, USA) and Survanta (Beractant, Ross Laboratories, Columbus, Ohio, USA). ${ }^{45}$

Inhaled NO has been shown to improve oxygenation and survival in a lamb model of persistent pulmonary hypertension (PPHN). ${ }^{46}$ Several case reports now indicate that inhaled NO may improve oxygenation in neonates with $\mathrm{CDH} .{ }^{7448}$ Short term NO inhalation in $\mathrm{CDH}$ has been shown to improve oxygenation in neonates with $\mathrm{CDH}$ only after decannulation from extracorporeal membrane oxygenation (ECMO). It is speculated that this is related to maturation of the endogenous surfactant system during ECMO. ${ }^{8}$ In contrast to infants with $\mathrm{CDH}$, those with PPHN respond dramatically to inhaled NO. ${ }^{76}$ This disparity in response to inhaled NO lies in the unique pathophysiology of $\mathrm{CDH} .{ }^{89}$ It appears that exogenous surfactant is required in the lamb model of $\mathrm{CDH}$ for delivery of inhaled NO to the terminal lung units, where it works synergistically with exogenous surfactant to decrease intrapulmonary shunting and PAP. ${ }^{9}$ Similar efficacy has been achieved with combination inhaled $\mathrm{NO}$ and high frequency oscillating ventilation (HFOV) or perfluorocarbon associated gas exchange (PAGE), probably for the same reason. ${ }^{46490}$ All these strategies emphasise alveolar recruitment of the atelectatic, surfactant deficient lungs in $\mathrm{CDH}$. Unless this strategy is utilised, NO may not be delivered to the alveolar capillary interface where it stimulates smooth muscle cell relaxation.

\section{Neonatal resuscitation}

An echocardiogram should be performed early to determine if any structural abnormalities exist, to assess for the presence of pulmonary hypertension, and to measure left ventricular mass index and left-to-right shunt fraction, to be repeated as frequently as necessary to reassess pulmonary haemodynamics and identify the direction of ductal level shunting, if any. If pulmonary hypertension with rightto-left shunting, left ventricular dysfunction, or systemic hypotension exist, vigorous use of inotropic agents is suggested to improve left ventricular function, increase systemic blood pressure, and reverse the right-to-left shunt. Efforts should be made to prevent factors that have been shown to increase pulmonary vascular resistance - for example, hypoxia, hypercarbia, acidosis, and hypothermia. We recommend gentle mechanical ventilation during this period in order to maintain a postductal saturation above $90 \%$. The peak inspiratory pressure (PIP) should never exceed the steep portion of the pressure-volume (PV) curve generated by online pulmonary function machines (PEDS; MAS Inc, Philadelphia, Pennsylvania, USA). For each patient treated, individual PV data should be generated repeatedly to optimise ventilatory settings and to help avoid barotrauma to the hypoplastic and surfactant deficient lungs. Although more controversial, $\mathrm{PCO}_{2}$ should be maintained at or below $8 \mathrm{kPa}$. No effort should be made to normalise $\mathrm{PCO}_{2}$ at the expense of significant barotrauma, which may further compromise the quantitative surfactant deficiency with proteinaceous and/or bloody exudate. ${ }^{24}$ Some centres have advocated "permissive hypercapnia" which tolerates moderately high $\mathrm{PCO}_{2}$ levels as long as a post-ductal arterial $\mathrm{Po}_{2}$ is maintained above $90 \% .^{51}$ This strategy avoids overt barotrauma of the lungs. ${ }^{5152}$ In a small, non-randomised series Wung et al reported survival of $94 \%$ using this technique, avoiding ECMO in $95 \%$ of their patients. ${ }^{51}$ Kays et al have successfully used a similar strategy with a survival rate exceeding $94 \%$ compared with $47 \%$ using standard therapy in combination with ECMO.$^{52}$

Although less efficacious, neonates transferred to a tertiary care centre after a variable period of failed conventional mechanical ventilation should be considered for rescue with exogenous surfactant. Again, we recommend $100 \mathrm{mg} / \mathrm{kg}$ of a calf lung surfactant preparation given in a single dose with repeated doses if necessary. Need for continued gentle mechanical ventilation, support for inhaled nitric oxide therapy, HFOV, or ECMO therapy should be considered once these neonates arrive at tertiary care centres as they invariably have suffered significant barotrauma.

\section{TIMING OF SURGERY AND ECMO}

It has been shown that a delayed surgical approach, enabling preoperative stabilisation of these critically ill neonates, decreases morbidity and mortality. ${ }^{53-56}$ Several reports now indicate that circulatory stability, respiratory mechanics, and gaseous exchange deteriorate after repair of $\mathrm{CDH} .{ }^{53556} \mathrm{It}$ is therefore better to stabilise the patient before attempting surgical repair. Although the ideal time to repair the diaphragmatic hernia is unknown, it has been suggested that 24 hours after stabilisation is ideal but, in fact, delays of up to 7-10 days are tolerated well. ${ }^{57-59}$ It is probably prudent to operate on these neonates when echocardiographic evidence for normal pulmonary artery pressures is maintained for at least $24-48$ hours. ${ }^{60}$

ECMO has become the final instrument to salvage the neonate with $\mathrm{CDH}$ who is refractory to conventional medical management. ${ }^{6162}$ Although initial reports did not indicate improved survival with ECMO, more recent series have reported survival of $80-90 \% .^{62}$ The timing of operation also remains a major issue as it relates to ECMO therapy. The potential advantages of operating while on ECMO is based on the observation that postoperative 
decline in pulmonary function can be controlled and recurrent pulmonary hypertension can be treated. $.^{563} \mathrm{Ob}-$ viously, the major disadvantages for operating on ECMO are haemostatic. ${ }^{6364}$ Although repairing the diaphragmatic hernia after decannulation from ECMO reduces the risk of haemorrhage, it has a significant disadvantage - namely, the inability to continue ECMO support if recurrent pulmonary hypertension develops. ECMO recannulation may be necessary in these cases. It has been shown, however, that neonates with pulmonary hypertension who are "nonresponders" to inhaled NO before placement on ECMO may become "responders" after decannulation from ECMO ${ }^{8}$ It is therefore possible to treat recurrent pulmonary hypertension with inhaled NO following decannulation from ECMO, avoiding a second run of ECMO ${ }^{8}$ Differences in response to inhaled NO before ECMO and following decannulation from ECMO may be due to several factors - for example, time on ECMO, anatomical and functional vascular recovery, and surfactant maturation. ${ }^{8}$

If lung size is not sufficient to support extrauterine life, then ECMO will prolong life but will not affect the outcome as it does not treat pulmonary hypoplasia. ${ }^{65}$ To overcome this dilemma, many centres have developed rigid entry criteria in addition to the gestational age, birth weight, and absence of lethal associated abnormalities. Another important criterion is a blood gas tension that is indicative of sufficient lung parenchyma to allow both oxygenation and ventilation. This is usually defined as a best postductal $\mathrm{PCO}_{2}$ exceeding $13.3 \mathrm{kPa}(100 \mathrm{~mm} \mathrm{Hg}) .{ }^{66}$ These classification schemes need modification as atelectatic lungs are surfactant deficient and best post-ductal blood gas tensions may not be indicative of life threatening lung hypoplasia but of inadequate alveolar recruitment. Optimisation of total lung capacity (TLC) and functional residual capacity (FRC) using combinations of the modalities described here are required before it is determined that lethal hypoplasia exists - "making the most out of the least".

\section{LIQUID VENTILATION}

Liquid ventilation has been shown to be effective in premature surfactant deficient animal models of respiratory insufficiency, improving compliance, gas exchange, and survival when compared with conventional mechanical ventilation. ${ }^{67}$ PAGE has been used in the lamb model of $\mathrm{CDH}$, both prophylactically and as rescue therapy. ${ }^{49} 5068$ In PAGE the lungs are filled with perfluorocarbon to a physiological FRC. By maintaining FRC, altered surface tension induced alveolar collapse is reduced. Perfluorocarbons have a surface tension of approximately 19 dynes/cm, which allows them to serve as excellent substitutes for surfactant. ${ }^{68}$ A low surface tension environment is produced which allows for optimal alveolar recruitment and effective gas exchange during ventilation. These properties enable PAGE to be clinically useful when the surfactant system is abnormal. Our preliminary results have shown that PAGE significantly improves gas exchange, dynamic compliance, and tidal volumes when used either prophylactically or as rescue therapy. ${ }^{495}$ It has also been shown that inhaled NO can be delivered during PAGE to reduce pulmonary pressures and further enhance oxygenation. ${ }^{450}$ Further studies are necessary to improve our understanding of PAGE and to assess its impact on pulmonary blood flow and haemodynamics. ${ }^{49} 50$ Clinical trials for the treatment of $\mathrm{CDH}$ will be initiated in the near future.
This work was supported in part by grants from the American Lung Association, the Women's and Children's Health Research Foundation, National Institutes of Health Grant HL 36543, HL 49977, and by the US Surgical Corporation, Norwalk, Connecticut, USA.

Correspondence to: Dr P L Glick.

Buffalo Institute of

Fetal Therapy (BIFT),

The Children's Hospital of Buffalo,

HRATCH L KARAMANOUKIAN

STUART J O'TOOLE BRUCE A HOLM

School of Medicine and

Biomedical Sciences,

Buffalo, New York, USA

1 Puri P, Gorman F. Lethal non pulmonary anomalies associated with congenital diaphragmatic hernia: implications for early intrauterine surgery. f Pediatr Surg 1984;19:29-32.

2 Harrison MR, Bressack MA, Churg AM. Correction of congenital diaphragmatic hernia in utero. I. The model: Intrathoracic balloon produces fetal pulmonary hypoplasia. Surgery $1980 ; 88: 174-82$.

3 Harrison MR, Jester JA, Ross NA. Correction of congenital diaphragmatic hernia in utero II: Simulated correction permits fetal lung growth with survival at birth. Surgery 1980;88:260-8.

4 D'Agostino JA, Bernbaum JC, Gerdes M. Outcome for infants with congenital diaphragmatic hernia requiring extracorporeal membrane oxygenation: the first year. F Pediatr Surg 1995;30:10-15.

5 Areechon W, Reid L. Hypoplasia of the lung associated with congenital diaphragmatic hernia. BMF 1963;1:230-3.

6 Nguyen L, Guttman FM, DeChadarevian JP, Beardmore HE, Karn GM Owen HF, et al. The mortality of congenital diaphragmatic hernia. Is total pulmonary mass inadequate, no matter what? Ann Surg 1983;198:766-9. pulmonary mass inadequate, no matter what? Ann Surg 1983;198:766-9.
Kinsella JP, Neish SR, Ivy DD, Shaffer E, Abman SH. Clinical responses to prolonged treatment of persistent pulmonary hypertension of the
newborn with low doses of inhaled nitric oxide. F Pediatr 1993;123:103-8.

8 Karamanoukian HL, Glick PL, Zayek M, Steinhorn RH, Zwass MS Fineman JR, et al. Inhaled nitric oxide in congenital hypoplasia of the lungs due to diaphragmatic hernia or oligohydramnios. Pediatrics 1994 94:715-8

9 Karamanoukian HL, Glick PL, Wilcox DT, Rossman J, Holm BA, Morin III FC. Pathophysiology of congenital diaphragmatic hernia VIII: Inhaled nitric oxide requires exogenous surfactant therapy in the lamb congenita diaphragmatic hernia model. F Pediatr Surg 1995;30:1-4.

10 Geggel RL, Murphy JD, Langleben D, et al. Congenital diaphragmatic hernia: arterial structural changes and persistent pulmonary hypertension after surgical repair. 7 Pediatr 1985;107:457-64.

11 Shochat SJ. Pulmonary vascular pathology in congenital diaphragmatic hernia. Pediatr Surg Int 1987;2:331-5.

12 Allen SW, Charfield BA, Koppenhafer SA, Schaffer MS, Wolfe RR, Abman SH. Circulating immunoreactive endothelin 1 in children with pulmonary hypertension. Am Rev Respir Dis 1993;148:519-22.

13 Kobayashi H, Puri P. Plasma endothelin levels in congenital diaphragmatic hernia. F Pediatr Surg 1994;29:1258-61.

14 Ford WDA, James WJ, Walsh JA. Congenital diaphragmatic hernia: association between pulmonary vascular resistance and plasma thromboxane concentrations. Arch Dis Child 1984;59:143-6.

15 Ford WDA, Sen S, Barker AP, Lee CM. Pulmonary hypertension in lambs with congenital diaphragmatic hernia: vasodilator prostaglandins, isoprenaline and tolazoline. $\mathcal{F}$ Pediatr Surg 1990;25:487-91.

16 Ein SH, Barker G. The pharmacological treatment of newborn diaphragmatic hernia - update 1987. Pediatr Surg Int 1987;2:341-5.

17 Karamanoukian HL, O,Toole SJ, Glick PL. Decreased pulmonary nitric oxide synthase activity in the lamb model of congenital diaphragmatic hernia. F Pediatr Surg (submitted).

18 Karamanoukian HL, Peay T, Love JE, Dandonna P, Abdel Rahman E, Azizkhan RG, et al. Decreased pulmonary nitric oxide synthase activity in the rat model of CDH. I Pediatr Surg 1996;31:1016-9.

19 Cloutier R, Fournier L, Levasseur M. Reversion to fetal circulation in congenital diaphragmatic hernia: a preventable postoperative comcongenital diaphragmatic hernia: a p
plication. $\mathcal{F}$ Pediatr Surg 1983;18:551-4.

20 Wigglesworth JS, Desia R, Guerrini P. Fetal lung hypoplasia: biochemical and structural variations and their possible significance. Arch Dis Child and structural varia

21 Berk C, Grundy M. High risk lecithin sphingomyelin ratios associated with neonatal congenital diaphragmatic hernia: case reports. Br f Obste Gynaecol 1982;89:250-1.

22 Hisanga S, Shimokawa $H$, Kashiwabara Y, Maesoto S, Nakano H. Unexpected low lecithin/sphingomyelin ratio associated with fetal diaphragmatic hernia. Am f Obstet Gynecol 1984;27:905-6.

23 Glick PL, Stannard VA, Leach CL, Rossman J, Hosada Y, Cooney DR, et al. Pathophysiology of congenital diaphragmatic hernia II. The fetal lamb CDH model is surfactant deficient. F Pediatr Surg 1982;27:382-8.

24 Wilcox DT, Glick PL, Karamanoukian HL, Rossman J, Morin III FC, Holm BA. Pathophysiology of congenital diaphragmatic hernia V: Effect of surfactant replacement therapy on gas exchange and lung mechanics in the lamb model congenital diaphragmatic hernia model. F Pediatr Surg 1984;124:289-93.

25 Glick PL, Leach CL, Besner GE, Egan EA, Morin III FC. Pathophysiology of congenital diaphragmatic hernia III. Exogenous surfactant therapy for the high risk neonate with CDH. F Pediatr Surg 1992;27:866-9.

26 O'Toole SJ, Karamanoukian HL, Morin III FC, Azizkhan RG, Holm BA Glick PL. Surfactant decreases pulmonary vascular resistance in the lamb model of congenital diaphragmatic hernia. Pediatr Res 1996;31:507-11.

27 Harrison MR, Langer JC, Adzick NS, Golbus NS, Filly RA, Anderson RL et al. Correlation of congenital diaphragmatic hernia in-utero. V: Initial clinical experience. F Pediatr Surg 1990;25:47-57.

28 Wilcox DT, Karamanoukian HL, Glick PL. Care of the fetus/newborn with congenital diaphragmatic hernia. Fetal Maternal Med Rev 1994;6:81-4.

29 Karamanoukian HL, Glick PL. Cardiac function in fetuses with congenital diaphragmatic hernia. $\mathscr{f} A M A$ 1994;272:29. 
30 Adzick NS, Harrison MR, Glick PL, Nakayama DK, Manning FA, deLorimier AA. Diaphragmatic hernia in the fetus: prenatal diagnosis and outcome in 94 cases. F Pediatr Surg 1985;20:357-61.

31 Steinhorn RH, Kriesmer PJ, Green PP, Payne WR. Natural history of congenital diaphragmatic hernia in Minnesota: impact of in utero diagnosis on survival. Arch Pediatr Adol Med 1994;148:626-31.

32 Karamanoukian HL, Wilcox DT, Glick PL. In-utero repair of prenatally diagnosed congenital diaphragmatic hernia (letter). F Pediatr Surg 1994; 29:954-5.

33 Siebert JR, Haas JE, Beckwith JB. Left ventricular hypoplasia in congenital diaphragmatic hernia. $\mathcal{F}$ Pediatr Surg 1984;19:567-71.

34 Karamanoukian HL, Glick PL, Wilcox DT, Rossman J, Azizkhan RG. Pathophysiology of congenital diaphragmatic hernia XI: Anatomic and biochemical verification of the hypoplastic heat in the lamb model of biochemical verification of the hypoplastic heat in the lamb

35 Crawford DL, Wright VM, Drake DP, Allan LD. Fetal diaphragmatic hernia: the value of fetal echocardiography in the prediction of postnatal outcome. Br f Obstet Gynaecol 1989;96:705-10.

36 Sharland GK, Lockhart SM, Heward AJ, Allan DL. Prognosis in fetal diaphragmatic hernia. Am f Obstet Gynecol 1992;166:9-13.

37 Karamanoukian HL, O'Toole SJ, Rossman JR, Sharma A, Holm BA, Azizkhan RG. Can cardiac weight predict lung weight in CDH? $\mathcal{F}$ Pediatr Surg 1996;31:823-5.

38 Hedrick MH, Estes JM, Sullivan KM, Bealer JF, Kitterman JA, Flake AW, et al. Plug the lung until it grows (PLUG): a new method to treat congenital diaphragmatic hernia in utero. F Pediatr Surg 1994;29:612-7.

39 DiFiore JW, Fouza DO, Slavin R, Wilson JR. Experimental fetal tracheal ligation and congenital diaphragmatic hernia: a pulmonary vascular morligation and congenital diaphragmatic hernia: a p
phometric study. $\mathcal{F}$ Pediatr Surg 1994;29:248-57.

40 O'Toole SJ, Sharma A, Karamanoukian HL, Holm BA, Azizkhan RG, Glick PL. Tracheal ligation does not correct the surfactant deficiency in Glick PL. Tracheal ligation does not correct the surfactant deficien

41 Wilcox DT, Glick PL, Karamanoukian HL, Azizkhan RG, Holm BA. Pathophysiology of congenital diaphragmatic hernia XII: Amniotic fluid lecithin/sphingomyelin ratios and phosphatidylglycerol concentration does not predict pulmonary surfactant status in congenial diaphragmatic hernia. f Pediatr Surg 1995;30:410-2.

42 Sullivan KM, Hawgood S, Flake AW, Harrison MR, Adzick NS. Amniotic fluid phospholipid analysis in the congenital diaphragmatic hernia fetus. F Pediatr Surg 1994;29:1020-3.

43 Karamanoukian HL, O'Toole SJ, Glick PL. Further evidence for surfactant deficiency in CDH. F Pediatr Surg 1994;29:1634-6.

44 Kendig JW, Notter RH, Cox CC, Reubens LJ, Davis JM, Maniscalco WM, et al. A comparison of surfactant as immediate prophylaxis and as rescue therapy in newborns of less than 30 weeks' gestation. N Engl f Med 1991; 324:865-71.

45 Cummings JJ, Holm BA, Hudak ML, Hudak BB, Ferguson WH, Egan EA. A controlled clinical comparison of four different surfactant preparations in surfactant deficient preterm lambs. Am Rev Respir Dis 1992;145: in surfactant

46 Zayek M, Wild L, Roberts JD, Morin III FC. Effect of nitric oxide on the survival rate and incidence of lung injury in newborn lambs with persistent pulmonary hypertension. F Pediatr 1993;123:947-52.

47 Hennenberg S, Jepsen S, Anderson PK, Pedersen SA. Inhalation of nitric oxide as a treatment of pulmonary hypertension in congenital diaphragmatic hernia. F Pediatr Surg 1995; 6:853-5.

48 Frostell CG, Lonnqvist PA, Sonesson SE, Gustafsson LE, Lohr G, Noak G. Near fatal pulmonary hypertension after surgical repair of congenital diaphragmatic hernia. Anesthesia 1993;48:679-83.
49 Wilcox DT, Glick PL, Karamanoukian HL, Leah C, Morin III FC, Fuhrman B. Perfluorocarbon associated gas exchange improves pulmonary mechanics, oxygenation and allows nitric oxide delivery in the hypoplastic lung congenital diaphragmatic hernia lamb model. Crit Care Med 1995;23 $1858-63$.

50 Wilcox DT, Glick PL, Karamanoukian HL, Azizkhan RG, Fuhrman B, Azizkhan RG, et al. Perfluorocarbon associated gas exchange and nitric oxide in congenital diaphragmatic hernia. Pediatrics (in press).

51 Wung JT, Sahni R, Moffitt ST, Stylianos S, Stolar CJ. Survival with congenital diaphragmatic hernia treated with delayed surgery, spontaneous respiration and no tube thoracostomy. Pediatr Res 1994;35:261A.

52 Kays DW, Langham MR, Ledbetter DJ. Detrimental effects of standard therapy in congenital diaphragmatic hernia. $\mathcal{F}$ Pediatr Surg (in press).

53 Langer JC, Filler RM, Bohn DJ, Shandling B, Ein SH, Wesson DE, et al. Timing of surgery for congenital diaphragmatic hernia: is emergency Timing of surgery for congenital diaphragmatic
operation necessary? f Pediatr Surg 1988;23:731-4.

54 Goh DW, Drake DP, Brereton RJ, Kiely EM, Spitz L. Delayed surgery for congenital diaphragmatic hernia. Br f Surg 1992;79:644-6.

55 Shanbhouge LKR, Tam PKH, Ninan G, Lloyd DA. Preoperative stabilization in congenital diaphragmatic hernia. Arch Dis Child 1990;65: 1043-4

56 Sakai H, Tamura M, Hosokawa Y. Effect of surgical repair on respiratory mechanics in congenital diaphragmatic hernia. $\mathcal{F}$ Pediatr 1987;111:432-8.

57 Nakayama DK, Motoyama EK, Tagge EM. Effect of preoperative stabilization on respiratory system compliance and outcome in newborn infants with congenital diaphragmatic hernia. $\mathcal{F}$ Pediatr 1991;118:793-9.

58 West KW, Bengston K, Rescorla FJ, Engle WA, Grosfeld L. Delayed surgica repair and ECMO improves survival in congenital diaphragmatic hernia. Ann Surg 1992;216:454-60.

59 Breaux CW, Rouse TM, Cain WS, Georgeson KE. Improvements in survival of patients with congenital diaphragmatic hernia utilizing a strategy of delayed repair after medical and/or extracorporeal oxygenation stabilization. $\mathcal{F}$ Pediatr Surg 1991;26:333-8.

60 Haugen SE, Eiknes S, Kufaas T, Vik T, Eggan BM, et al. Congenital diaphragmatic hernia: determination of the optimal time for operation by echochardiographic monitoring of the pulmonary artery pressure. $\mathcal{F}$ Pediatr Surg 1991;26:560-2.

61 Bartlett RH, Grazzaniga AB, Tommasian J, Coran AG, Roloff D, Rucker R. Extracorporeal membrane oxygenation (ECMO) in neonatal respiratory failure, 100 cases. Ann Surg 1986;204:236-42.

62 Loe WA, Graves ED, Ochner JL, Falterman KW, Arensman RM. Extracorporeal membrane oxygenation for newborn respiratory failure. $\mathcal{F}$ tracorporeal membrane oxy

63 Lally KP, Paranka MS, Roden J, Georgeson KE, Wilson JM, Lillehei CW, t al. Congenital diaphragmatic hernia: stabilization and repair on ECMO. et al. Congenital diaphragmatic

64 Conners RH, Tracy T, Bailey PV, Kountzman B, Weber TR. Congenital diaphragmatic hernia repair on ECMO. F Pediatr Surg 1990;25:1043-7.

65 Stolar C, Dillon P, Reyes C. Selective use of extracorporeal membran oxygenation in the management of congenital diaphragmatic hernia. $\mathcal{F}$ Pediatr Surg 1988;23:207-11

66 Bohn D, Tamura M, Perrin D, Barker G, Rabinovitch M. Ventilatory predictors of pulmonary hypoplasia in congenital diaphragmatic hernia, confirmed by morphologic assessment. F Pediatr 1987;111:423-31.

67 Leach CL, Fuhrman BP, Morin FC, Rath MG. Perfluorocarbon associated gas exchange (partial liquid ventilation) in respiratory distress syndrome. Crit Care Med 1993;21:1270-8.

68 Major D, Cadenas M, Cloutier R. Combined gas ventilation and perfluorochemical tracheal instillation as an alternative treatment for neardeath congenital diaphragmatic hernia. F Pediatr Surg 1995;30:1178-82. 